\title{
Estimation of Length-Weight Relationship and Proximate Composition of Catfish (Clarias gariepinus Burchell, 1822) from Two Different Culture Facilities
}

\author{
Olaniyi Alaba Olopade*, Mercy Gbaramana, Nenibarini Zabbey
}

Department of Fisheries, University of Port Harcourt, Port Harcourt, Nigeria.

\section{A R T I C LE INFO}

\section{Article history:}

Received 31 January 2015

Accepted 05 June 2015

Available online, ISSN: 2148-127X

\section{Keywords.}

Earthen pond

Concrete tanks

Proximate composition

Length-weight relationship

Clarias gariepinus

" Corresponding Author:

E-mail: oaolopade@yahoo.com

\author{
A B S T R A C T
}

This study was carried out to determine and compare the proximate composition and length weight relationship of $C$. gariepinus from two culture systems (earthen and concrete ponds). The fish samples were collected from three fish farms with same cultural condition in different areas of Obio-akpor Local Government Area of Rivers State, Nigeria. Result on the length- weight relationship revealed that C.gariepinus reared in concrete tank had a total length of $15.50-49.00 \mathrm{~cm}$ with a mean of $32.71 \mathrm{~cm}$ and weight of $150-625 \mathrm{~g}$, while total length of $C$. gariepinus reared in the earthen pond ranged from $19.90-58.0 \mathrm{~cm}$ with a mean of $39.8 \mathrm{~cm}$ and weight of $195-825 \mathrm{~g}$. The T- test shows that the total length of earthen pond were significantly higher than the concrete tank and the weight in the earthen pond was significantly higher than the concrete tank. Parameters of proximate composition analysed were moisture, protein, lipid, carbohydrate, ash and fiber from the fish flesh. Protein content showed a significantly higher in the earthen ponds than the concrete tanks. Ash contents varied from $1.5 \pm 1.66-7.4 \pm 0.67 \%$ in the concrete tanks and were significantly higher than the earthen ponds which ranged from $3.1 \pm 0.94$ $4.5 \pm 2.11 \%$. Lipid was significantly higher in earthen ponds than concrete tanks. Generally, the two culture systems have a significant influence on length-weight relationship and nutritional value of $C$. gariepinus. However, C. gariepinus reared in concrete tank had a heavier body weight than earthen pond and also C. gariepinus reared in earthen pond had highest nutritive values than the concrete tank.

\section{Introduction}

Aquaculture system is defined in terms of species, culture facility and husbandry. The type of culture facility chosen depends on several factors, some of which include: type of species to be raised, climate of area, location of site, available funding for a structure, and size of the operation. Culture facilities in which fish are reared are ponds, tanks, recirculation systems, raceways, and cages in river or tidal streams. They have been developed to meet the economic needs of the fish farmers and the requirements of the species to be cultured. The type of culture medium used and their management have a significant influence on fish farm profitability (Ross and Waten, 1995) and the quality of fish products.

The most common production system in use is the earthen pond and has been in use dating back to time immemorial. Typical fish ponds are earthen enclosures in which the fish live in a natural-like environment, feeding on the natural food growing in the pond itself from sunlight and nutrients available in the pond water. In order to reach higher yields, farmers today introduce nutrients (organic manure) and additional food. Pond culture has a number of advantages in terms of production efficiency, ease of construction, low maintenance and it offers a variety of ecological niches which can support numerous and diverse organisms.

The introductions of concrete tanks allow for manageable pond size, greater human control in operations and facilitate intensive farming thus allowing for higher fish yield. Concrete fish tanks have come into greater prominence since they make aquaculture practices possible in locations of limited water supply with the advantage of better medium control and facilitate fish handling. This type of production system is common in most urban and pre - urban cities in Nigeria particularly where land is not available or suitable for earthen pond construction (Omitoyin, 2007).

Catfish farming is gradually gaining prominence in Nigeria due to several promotional programmes launched by government agencies and measured to support aquaculture development. Currently, the species mostly cultured are Clarias gariepinus, Heterobranchus sp. and their hybrids in Nigeria (Adewolu et al., 2008). The earthen ponds and tanks are the commonly used culture facilities for catfish in Nigeria. However, the variations in the two holding facilities may have direct bearing on body composition, health status and growth of fish. 
A clear understanding of the growth pattern of the farmed fish and quality are necessary to determine the best culture facility for catfish. In Nigeria, the knowledge of length-weight relationship and proximate composition of Clarias gariepinus cultured in the earthen ponds and concrete tanks are still inadequate .The primary objective of this present study was to identify and compare lengthweight relationship and nutritional elements of Clarias gariepinus from two culture systems (earthen ponds and concrete tanks).

\section{Materials and Methods}

\section{Fish Samples}

Three fish farms (Victory Integrated Farm Aluu, Justin Farm Aluu, and Amakiri Farm) of C. gariepinus with similar cultural conditions were selected in different areas of Obio-akpor Local Government Area of Rivers State. Cultural conditions were similar from the viewpoint of fish nutrition, size of aquaculture facilities and water management in the selected farms. Fish foods used in all the fish farms were prepared from the same factory (Vital feeds). The fingerlings with average body weight $5.67 \pm$ $0.42 \mathrm{~g}$ and average length $10.03 \pm 1.22 \mathrm{~cm}$ were stocked at the same time in early March 2013 and the fish samples were collected during July 2013, with the farmers catching it with various fishing gears such as beach seines, scoop nets and baskets. Ten cultured $C$. gariepinus market size fish were collected from each of the cultured systems in each of the farm. The fish samples were transported live to the laboratory for analysis. Total length and body weight of each sample were measured to the nearest centimeter on a measuring board and weighed to the nearest gram on a weighing balance. The fish was killed, and the muscle sample was removed from the left side of the fish between the dorsal fin and the operculum, and was weighed to determine the tissue weight composition of the fish flesh and was cleaned, filleted and homogenized for $15 \mathrm{mins}$. The samples for the different chemical analysis were then taken from the homogenous material. The percentage of proximate composition of fish was determined by conventional method of AOAC (2000). The muscle proximate analysis consisted of determining moisture, crude protein, crude fat, and crude ash. Moisture content was determined by drying samples in an oven at $105^{\circ} \mathrm{C}$ until a constant weight was obtained (AOAC, 1990). Crude protein content was determined by the Kjeldahl method (AOAC, 1990), and a conversion factor of 6.25 was used to convert total nitrogen to crude protein. Fat extraction was done following the method of Bligh and Dyer (1959), with slight modifications by Kinsella et al. (1977). Crude ash was determined by incineration in a muffle furnace at $550^{\circ} \mathrm{C}$ for $24 \mathrm{~h}$ (AOAC, 1990).Carbohydrate content was calculated based on difference calculation [Carbohydrate $=100 \%$ $(\%$ moisture $+\%$ ash $+\%$ crude protein $+\%$ fat $)]$.Triplicate determinations were carried out on each chemical analysis.

Length-weight relationship: The length-weight (logtransformed) relationships were determined by linear regression analysis and scatter diagrams of length and weight were plotted. The length-weight relationship of the experimented fish is worked out as per cube law given by Le Cren (1951). The relationship between total weight (W) and total length (L) of the fish were estimated using the equation: $\mathrm{W}=\mathrm{aLb}$, where ' $\mathrm{a}$ ' is a constant and ' $\mathrm{b}$ ' is a regression coefficient relating weight ( $\mathrm{W}$ in grams) and length ( $\mathrm{L}$ in $\mathrm{cm})$, and was estimated by ordinary least square regression. After transforming the weight and length to logarithms the above equation was applied as follows: $\log \mathrm{W}=\log \mathrm{a}+\mathrm{b} \log \mathrm{L}$, calculated by the method of least square.

Statistical analysis

The values obtained by the analysis of different fish samples (ponds + tanks) was given as the means+ SE. the different between the mean values of the studied parameters was calculated by student $t$ test. Duncan multiple range test was applied, where required to distinguish the significance of various means. Calculations were done with SPSS Statistical package version 16.

\section{Results}

Length -Weight Measurement of Clarias gariepinus

The total length, standard length and weight measurement of $C$. gariepinus from the two cultured systems are presented in Table 1 . The total length of $C$. gariepinus in the earthen ponds ranged from 15.50 to $49.00 \mathrm{~cm}$ with a mean of $32.71 \pm 9.2 \mathrm{~cm}$ while the standard length varied between 12.30 and $46.00 \mathrm{~cm}$ with a mean of $29.79 \pm 9.2 \mathrm{~cm}$. In the concrete tank, the total length ranged from 19.90 to $58.0 \mathrm{~cm}$ with a mean of $39.86 \pm 8.1 \mathrm{~cm}$ and the standard length had a range of 13.00 to $52.0 \mathrm{~cm}$ with a mean of $34.77 \pm 8.3 \mathrm{~cm}$. The weight of $C$. gariepinus recorded in the earthen pond during the experimental period was lower than the earthen pond. In the earthen pond values ranged between 150 to $625 \mathrm{~g}$ with a mean of $348.41 \pm 13.93 \mathrm{~g}$ while the weight C.gariepinus in the concrete tank varied between 195 and $825 \mathrm{~g}$ with a mean of $522.2 \pm 15.02 \mathrm{~g}$.

The T- test in table (2) shows that the TL of concrete tank was significantly higher than earthen pond $(\mathrm{P}<0.005)$, and there were no significant difference in SL between concrete tank and earthen pond $(\mathrm{P}>0.005)$. The weight of C. gariepinus in the concrete tank were significantly higher than the weight of $C$. gariepinus in the earthen pond $(\mathrm{P}<0.01)$. The Pearson's correlation was also used to determine association between the parameters of total length, standard length and weight. Each of the parameters shows a 'strong' positive correlation with the others with significance $\mathrm{P}<0.001$ (Table 2).

The length-weight relationship of $C$. gareipinus reared in the earthen pond was represented by this equation Log $\mathrm{W}=-1.21+2.43 \log$. There was no significant difference between the exponent value and " 3 ". Hence, it can be concluded that the weight of $C$. gariepinus increases proportionately to the cube of the length as the exponent value was observed to be almost " 3 " (2.83). It clearly revealed that the fish is neither heavier nor lighter for its length in the concrete tank. A low exponential value was, however, observed to be significantly less than '3' (2.4) in 
the C.gariepinus reared in earthen pond. The co-efficient of correlation of $C$. gariepinus reared in earthen pond was 0.8991 and 0.9736 for concrete tank, which indicates that the relation between length and weight is in tune with the isometric growth (graph).

The values of protein content obtained in the three farms under study ranged from $13.13 \pm 0.89-18.19 \pm 3.11 \%$ in the earthen ponds, while in the concrete tank, the protein content was in range of $10.5 \pm 1.12-17.1 \pm 3.32 \%$ (Table 4). The result revealed that the protein content of C. gariepinus from the earthen pond was higher than the concrete tank. Similarly, when protein contents were compared between two cultured systems on the three farms, values were far higher in the earthen ponds in farm 1 and 2 than concrete tanks $(\mathrm{P}<0.05)$, while in farm 3 , there were no significant different in the two cultured systems $(\mathrm{P}>0.05)$. Carbohydrate content during the experimental period revealed that $C$. gariepinus had a very low level of $2.05 \pm 2.22-3.08 \pm 1.05 \%$ of carbohydrate in the earthen ponds and a value of $1.66 \pm 2.17$ $2.31 \pm 1.16 \%$ in the concrete tanks. The highest carbohydrate content was recovered from the earthen ponds in farm I and II and the lowest from that of concrete tanks, which were significantly higher $(\mathrm{P}<0.005)$ (Table 4). While in farm 3, there were no significant differences in both cultured systems.
Ash contents varied from $1.5 \pm 1.66-7.4 \pm 0.67 \%$ in the concrete tanks and were significantly higher $(\mathrm{P}<0.005)$ than the earthen ponds which ranged from 3.1 \pm 0.94 $4.5 \pm 2.11 \%$. However, when ash contents of $C$. gariepinus of the two cultured systems in farm land 2 were compared, the values were close to each other but there were not significant different $(\mathrm{P}>0.005)$. The lipid contents of $C$. gariepinus in the earthen ponds systems ranged between $3.5 \pm 2.01-8.3 \pm 1.17 \%$, while in the concrete tank, the value varied from $1.1 \pm 2.82-5.5 \pm 0.29 \%$. The fish lipids were significantly higher in earthen ponds in farm 1 and $2(\mathrm{P}<0.005)$ than the concrete tanks, while in farm 3, there were no significantly difference in both cultured systems. Moisture content differs among all the three farms irrespective of the cultured systems. Differences were very prominent when water contents were compared with those present in concrete tanks and were significantly $(\mathrm{P}<0.05)$ higher than the earthen ponds in farm I and II .In farm III, the moisture content were significantly higher in the earthen pond than the concrete tank. Fiber content values of $1.65 \pm 0.19-6.61 \pm 2.11 \%$ were observed in the concrete tanks and 3.03 $\pm 0.11-4.5 \pm 1.01 \%$ was recorded in the earthen pond. In farm II and III, there were no significant difference in both cultured systems, while in farm I, the fiber content were significantly higher in concrete tanks than earthen ponds $(\mathrm{P}<0.05)$.

Table1 Total Length, standard length and weight of C.gariepinus in the earthen pond and concrete tank

\begin{tabular}{l|llrrrr}
\hline Culture facilities & Parameters & N & Minimum & Maximum & Mean & Std. Deviation \\
\hline \multirow{3}{*}{ Earthen Pond } & TL $(\mathrm{cm})$ & 30 & 19.90 & 58.00 & 39.86 & 8.11 \\
& SL(cm) & 30 & 13.00 & 52.00 & 34.77 & 8.31 \\
& Weight $(\mathrm{g})$ & 30 & 195.00 & 825.00 & 522.27 & 15.02 \\
\hline \multirow{3}{*}{ Concrete Tank } & TL(cm) & 30 & 15.50 & 49.00 & 32.71 & 9.21 \\
& SL(cm) & 30 & 12.30 & 46.00 & 29.79 & 9.24 \\
& Weight $(\mathrm{g})$ & 30 & 150.00 & 625.00 & 348.41 & 13.93 \\
\hline
\end{tabular}

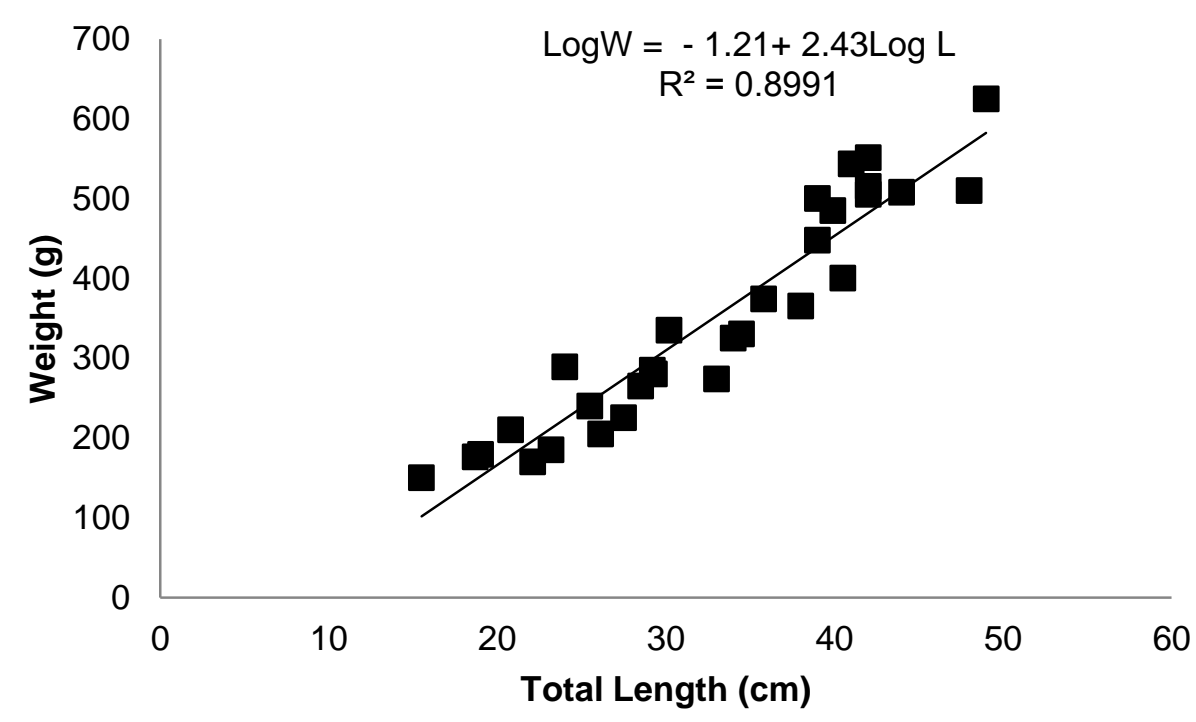

Fig. 1 Scatter diagram of absolute values showing the length-weight relationship of Clarias gariepinus from earthen pond 


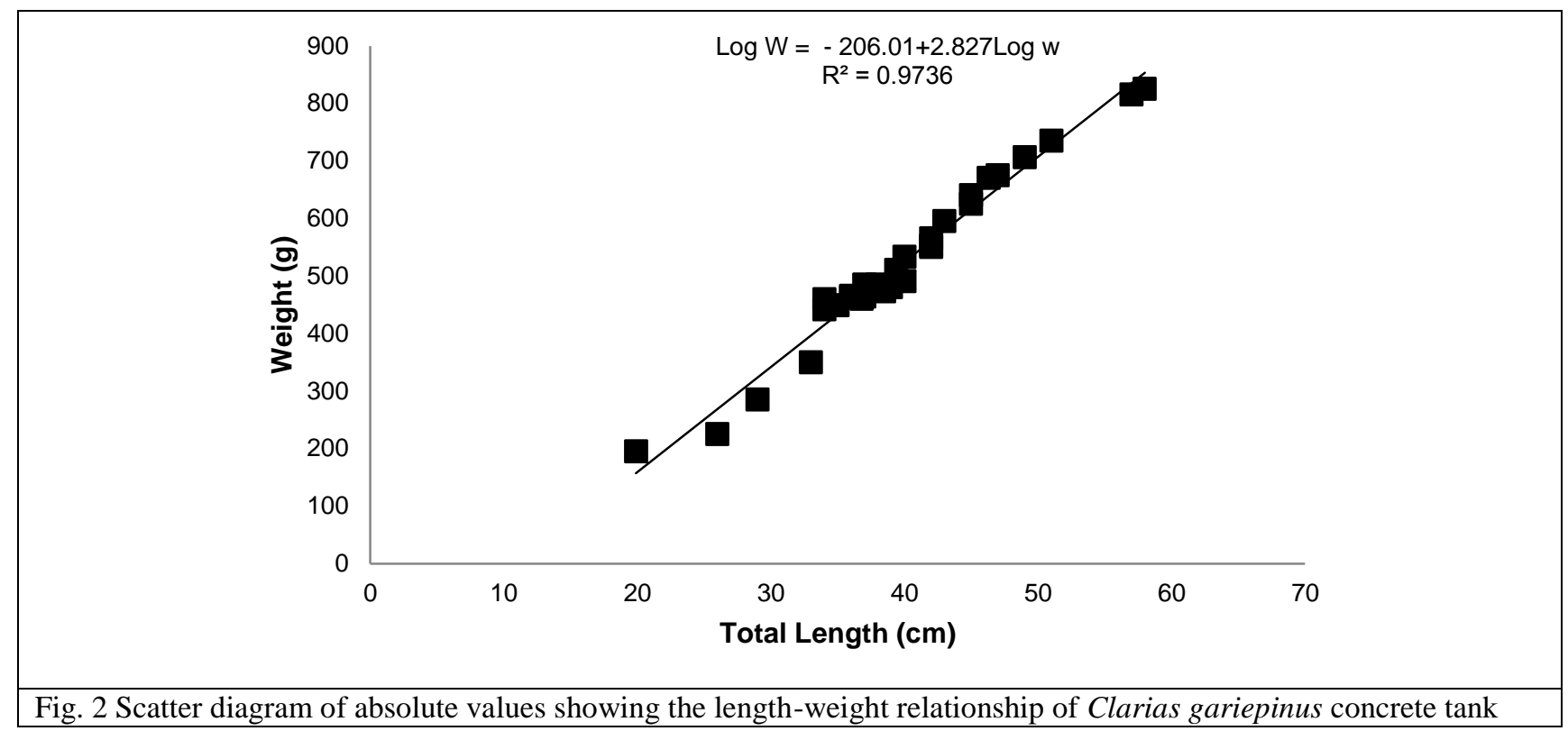

Table 2 Correlation matrix between total length, standard length and weight of $C$. gariepinus in the earthen pond and concrete tank,

\begin{tabular}{l|cc}
\hline \multirow{2}{*}{ Length and Weight } & Earthen Pond & Concrete Tank \\
\cline { 2 - 3 } & $\Upsilon$ & $0.998^{* *}$ \\
TL Vs SL & $0.990^{* *}$ & $0.948^{* *}$ \\
TL Vs WT & $0.987^{* *}$ & $0.946^{* *}$ \\
WT Vs SL & $0.983^{* *}$ &
\end{tabular}

Table 3 Proximate Composition of C.gariepinus Reared in the Concrete Tanks and Earthen Ponds

\begin{tabular}{l|llllllc}
\hline Farms & Culture Systems & Protein & Carbohydrate & Ash & Lipid & Moisture & Fiber \\
\multirow{2}{*}{ Farm 1 } & Earthen Pond & $13.13 \pm 0.89^{\mathrm{a}}$ & $3.08 \pm 0.01^{\mathrm{a}}$ & $4.5 \pm 2.11^{\mathrm{b}}$ & $4.5 \pm 3.17^{\mathrm{a}}$ & $70.29 \pm 2.9^{\mathrm{b}}$ & $4.5 \pm 1.01^{\mathrm{b}}$ \\
& Concrete Tank & $10.5 \pm 1.12^{\mathrm{b}}$ & $2.12 \pm 1.51^{\mathrm{b}}$ & $7.4 \pm 0.67^{\mathrm{a}}$ & $1.1 \pm 2.82^{\mathrm{b}}$ & $72.27 \pm 2.17^{\mathrm{a}}$ & $6.61 \pm 2.11^{\mathrm{a}}$ \\
\hline \multirow{2}{*}{ Farm 2 } & Earthen Pond & $15.75 \pm 0.95^{\mathrm{a}}$ & $3.08 \pm 1.05^{\mathrm{a}}$ & $3.1 \pm 0.94$ & $8.3 \pm 1.17^{\mathrm{a}}$ & $66.66 \pm 6.73^{\mathrm{b}}$ & $3.11 \pm 1.79$ \\
& Concrete Tank & $13.13 \pm 0.76^{\mathrm{b}}$ & $2.31 \pm 1.16^{\mathrm{b}}$ & $3.1 \pm 0.81$ & $5.5 \pm 0.29^{\mathrm{b}}$ & $72.96 \pm 7.11^{\mathrm{a}}$ & $3.00 \pm 2.05$ \\
\hline \multirow{2}{*}{ Farm 3 } & Earthen Pond & $18.19 \pm 3.11$ & $2.05 \pm 2.22$ & $3.05 \pm 1.85$ & $3.5 \pm 2.01$ & $73.5 \pm 4.33^{\mathrm{a}}$ & $3.03 \pm 0.11$ \\
& Concrete Tank & $17.1 \pm 3.32$ & $1.66 \pm 2.17$ & $1.5 \pm 1.66$ & $1.32 \pm 2.21$ & $70.43 \pm 1.49^{\mathrm{b}}$ & $1.65 \pm 0.19$ \\
\hline
\end{tabular}

\section{Discussion}

C. gariepinus reared in concrete tanks had a heavier body weight than $C$. gariepinus reared in earthen ponds. The value ranged between $625-825 \mathrm{~g}$ with an average mean of $348.4-522.2 \mathrm{~g}$ respectively. LWR for both cultured systems graphically represented in fig 1 and 2 . LWR of $C$. gariepinus in both culture systems conform to already record LWR of all species of the genus in Nigerian freshwater systems (Ezenwaji, 2004). A $\log$ transformed length-weight regression analysis for $C$. gariepinus in the earthen pond and concrete tank species revealed the following linear relations. It can be observed that the length increment responding with a highly increase in weight (0.899-0.973) consist of an exponential relationship which is relatively higher in concrete tank than earthen pond. However, the high value of $r$ indicates a good measures for the strength of these equation and closeness of observed and calculated value of the fish weight. The higher degree of positive correlation between total length and total weight in the two culture systems indicated by high value of correlation coefficient $r$ (Figs.1 and 2) which indicate increase in length with increase in weight. Result of current study revealed that cultured systems had a direct bearing on the nutritional quality of a fish. It has been reported that factors such as endogenous (genetic) and exogenous (related to diet and the environment) (Shearer, 1994) have an impact on the composition and quality of the aqua cultured fish.

The proximate composition of fish cultured in earthen ponds and concrete tanks showed significant higher moisture content in the concrete tank (72. 27- 72.96\%) than the earthen pond (66.66-70.29\%). Water is the element that has greatest quantity in the composition of fish species and its presence is inverse to the percentage of fat (Wheaterley et al. 1983) as shown in Table 4. In lipid, higher value of $8.3 \%$ were recorded in the earthen pond and were significantly higher $(\mathrm{P}<0.05)$ than the 
values in the concrete tanks $5.5 \%$.This findings is similar to that reported by Akinwumi et al. (2011) which observed that fresh fish had the lowest fat content of 8.57 $\pm 0.273 \%$. The high fat content recorded in this study is due to the composition of the diet it is fed but especially it is due to the high density of fishes in a same area that prevents them to swim in a freeway (Flos et al. 2002; Mnari 2007). Protein were significantly higher $(\mathrm{P}<0.05)$ in earthen ponds (13.13-15.75\%) and lower in concrete tank (10.5-13.13\%). Pond-reared fish, in contrast, obtain a significant proportion of their nutritional needs from pond biota. This is attributed to the fact that fishes cultured in earthen ponds tends to feed more on the available natural foods i.e algae, phytoplankton enriched in protein than the ones cultured in concrete tanks. Thus, this finding is similar to that reported by (Ros et al. 2010). The ash content in the concrete tanks was $7.4 \%$ and was significantly higher than the earthen ponds $4.5 \%$.The difference of the values may come from some extrinsic or intrinsic conditions to the species. Carbohydrate percentage of $2.05-3.08 \%$ in the concrete tanks were significantly higher $(\mathrm{P}<0.05)$ than the earthen ponds $(1.66-2.12 \%)$. The carbohydrate content in fish is generally very low and practically considered zero (Payne et al., 1999; Anthony et al., 2000). The low value recorded in this present study supports the view that carbohydrate plays an insignificant role as energy reserved in aquatic animal (Love et al., 1970). The fiber content in the concrete tank ranged from 1.65-6.61\% and in the earthen ponds it ranged from $3.03-4.5 \%$. The values recorded could be attributed the nature of feed used to feed the fish in the culture systems particularly in the earthen pond where there are natural foods.

\section{Conclusion and Recommendation}

LWR result showed that the Regression coefficient for C. gariepinus from the concrete tank and earthen pond did not differ significantly from the hypothesized value 3 . However, C. gariepinus reared in concrete tank had a heavier body weight than earthen pond. The result of the studies showed that in terms of protein content, lipid and carbohydrates, C. gariepinus reared in earthen pond had highest nutritive values than the concrete tank. Both cultured systems are good sources of fiber and ash required for good health. Although, the two culture systems show that $C$. gariepinus reared are highly nutritious- high in terms of protein, lipid, ash and a good source of carbohydrate. Consumers intending to increase their quality of protein intake can benefit from $C$. gariepinus reared in earthen ponds.

\section{References}

Adewolu MA, Ogunsanmi AO, Yunusa A. 2008. Studies on growth performance and feed utilization of two Clariid catfish and their hybrid reared under different culture systems. European J. of Sci. Res., 23: 252-260
Akinwumi FO, Fesobi ME, Akinwumi IO, Adejuyigbe AA. 2011. Effect of sun and oven drying on the proximate value of African mud catfish Clarias gariepinus (siluriformes, Clariidae) Burchel, 1822. Advances in food and energy security pp29-35.

Anthony JA, Roby DD, Turco KR. 2000. Lipid content and energy density of forage fishes from the Northern Gulf of Alaska. Journal of Experimental Marine Biology and Ecology 248: 5378.

AOAC. 1990 Official Method of Analysis (K Helrich, editor). Association of Official Analytical Chemists, Washington D.C., $15^{\text {th }}$ Edition. 1: 1094pp.

Association of Official Analytical Chemists Association of Official Analytical Chemists, (1994) Official Methods of Analysis of the Association of Official Analytical Chemists, vols 1\&11, Association of Analytical Chemists, Arlington.

AOAC. 2000. Official methods of Analysis (17th Edn).Association of Official Analytical Chemist, Washington. D.C.

Bligh EG, Dyer WJA. 1959. Rapid method of total lipid extraction and purification.Canadian J. Biochem. Physiol., 37: 911-917.

Ezenwaji HMG. 2004. Length-weight relationships of fishes from AnambraRiver, South-eastern, Nigerian. Animal Research International, 1:1-6.

Flos R, Reig L, Oca J, Ginovart M. 2002. Influence of marketing and different land-based system on gilthead sea bream (Spaurus aurata) quality. Aquac. Int. 10: 189-206.

Kinsella JE, Shimp JL, Mai J, Weihrauch J. 1977. Fatty acid content and composition of freshwater finfish. Journal of the American Oil Chemists' Society 54: 424-429.

Le-Cren ED. 1951. The length-weight relationship and seasonal cycle in gonad weight and condition in the perch \{Percaftuvitalis).J. Anim. EcoL, 20: $201-219$.

Love RM. 1970. The chemical biology of fishes. Academic Press New York.547 pp.

Miller JW, Atanda AN. 2004. Inventory of Fish Farms in Nigeria. Aquaculture and Inland Fisheries Project, National Special Programme for Food Security. 148p.

Mnari A, Bouhel I, Chraief I, Hammami M, Romdane MS, Chaouch A. 2007. Fatty acid in muscle and liver of Tunisian wild and farmed gilhead sea beam, (Spaurus aurata). Food Chemistry 100: 1393-1397.

Mumba PP, Jose M. 2005. Nutrient composition of selected fresh and processed fish species from lake Malawi: A nutritional possibility for people living with HIV/AIDS. International Journal of Consumer studies, 29:72-77.

Omitoyin BO. 2007. Introduction to Fish Farming in Nigeria. Ibadan University Press, University of Ibadan, Nigeria, pp. 3540.

Payne SA, Johnson BA, Otto RS. 1999. Proximate composition of some north-eastern Pacific forage fish species. Fish Oceanography 8: 159-177.

Ros G, Martinez C, Santaella M. 2010. Pescados y mariscos.En Tratado de Nutriciòn.Tomo II. Composiciòn y CalidadNutritiva de los Alimentos.Editorial MèdicaPanamericana. Madrid, España

Ross RM, Waten BJ. 1995. Importance of Rearing-unit Design and Stocking Density on the Behaviours, Growth and Metabolism of Lake Trout (Salvelinusnamaysuch). Aquaculture Engineering, pp. 40-45.

Shearer KD. 1994. Factors affecting the proximate composition of cultured fishes with emphasison salmonids. Aquaculture, 119, 63-88.

Tucker CS. 1998. The ecology of channel catfish ponds in northwest Mississippi. Reviews in Fisheries Science 4:1-55.

Wheaterley AH, Gill HS. 1983. Protein, lipid, water and caloric contents of immature rainbow trout, Salmogairdneri Richardson, growing at different rates. Journal of Fish Biology 23: $653-673$. 